DOI https://doi.org/10.15407/csc.2021.05-06.045

UDC 6:004.8

O.H. MOROZ, senior research scientist,

Department for Technologies of Inductive Modelling,

International Research and Training Center

for Information Technologies and Systems of the NAS and MES of Ukraine,

Glushkov ave., 40, Kyiv, 03187 , Ukraine,

olhahryhmoroz@gmail.com

\title{
THE PROBLEM OF CONSTRUCTIYG THE GMDH NEURAL NETWORKS WITH ACTIVE NEURONS
}

Characteristics of the existing neural networks of GMDH with active neurons are given and their main advantages and disadvantages are analyzed. An approach to increasing efficiency of inductive construction of complex system models from statistical data based on creation of a new class of GMDH neural networks with active neurons using methods of computational intelligence is proposed.

Keywords: inductive modeling, GMDH neural network, active neurons, computational intelligence, genetic algorithms.

\section{INTRODUCTIOY}

Neural networks based on a Multilayered Iterative Algorithm of Group Method of Data Handling (MIA GMDH) [1] are effective tools for solving current problems such as forecasting, data analysis, pattern recognition, clustering, classification and more. There are many types of GMDH neural networks [1], the development of which is aimed at overcoming the shortcomings of GMDH and increase its efficiency for the inductive construction of models of complex systems according to statistics. The most used of which are presented in [1].

The main disadvantages of the GMDH neural network are: the possibility of losing informative arguments, if they were excluded at the beginning of the search; the possibility of fixing non-informative arguments, if they were included at the beginning of the search; exponential growth of the degree of a polynomial in a quadratic description; as the number of series increases, the output vectors of the best models become more and more correlated, which worsens the conditionality of the systems of equations for estimating the parameters.

The latest modification of GMDH multi-row algorithms to eliminate their shortcomings is the generalized GMDH iterative algorithm [1-5], which is based on a combination of ideas to preserve the initial modeling basis and apply complexity optimization to partial models using so-called "active neurons" with different structures. is optimized by the combinatorial algorithm of GMDH. Its special cases are algorithms of multi-row and relaxation types, as well as some types of iterativecombinatorial (hybrid) algorithms.

This paper investigates the advantages and disadvantages of existing GMDH neural network architectures in order to further construct a more efficient new class of GMDH neural networks with active neurons, which is optimized by a hybrid combinatorial-genetic algorithm [6]. 


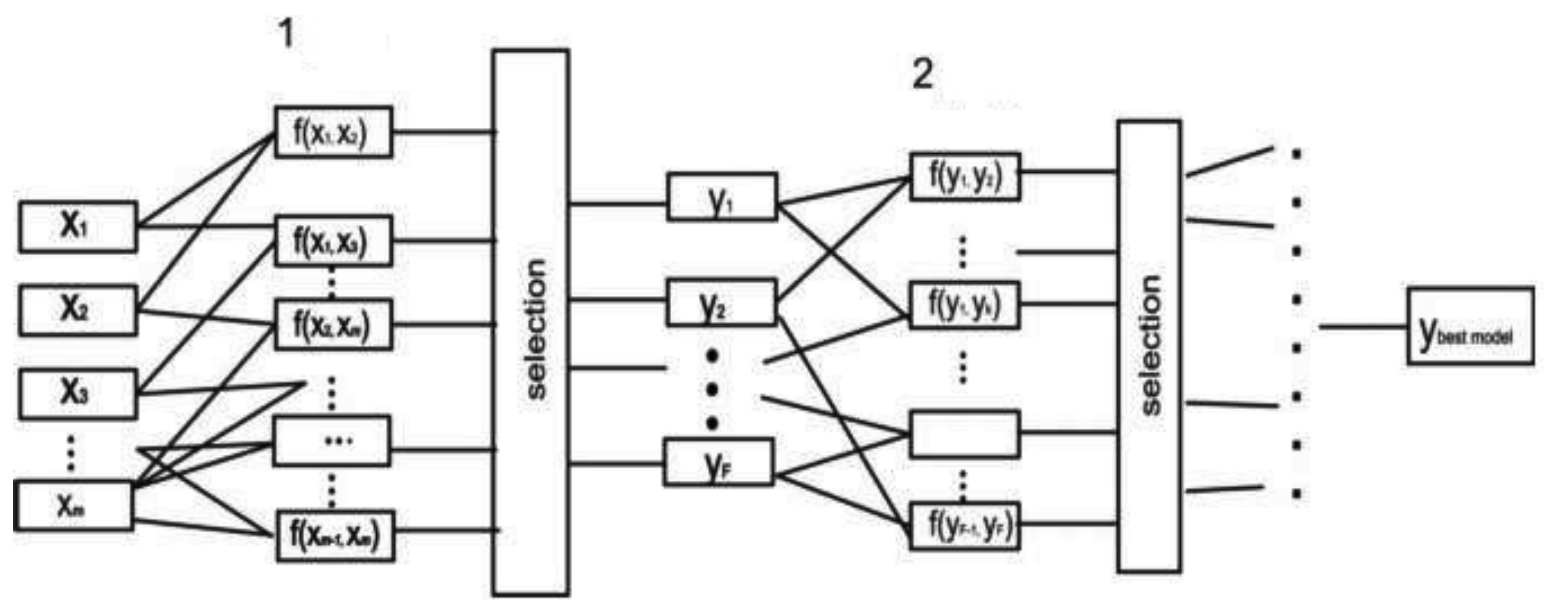

Fig. 1. The structure of the multi-row iterative algorithm MIA GMDH

\section{Statement of the Problem of Inductive Modeling}

The world-famous MIA GMDH [1] (Fig. 1) is an effective tool for data analysis, one of the most successful methods of inductive modeling, which extracts knowledge directly from data based on experimental measurements or statistical observations. It was developed by O. Ivakhnenko in 1965 as a multilayer neural network of the perceptron type, which belongs to the class of deep polynomial neural networks with a theoretically unlimited number of layers that are set in the learning process. Now it is considered to be the first in the history of multilevel self-organizing $\mathrm{NM}$, and $\mathrm{O}$. Ivakhnenko is often called the father of deep learning [1]. The GMDH algorithm was first used in the modeling of complex systems with multiple inputs and one output.

The main purpose of the GMDH network is actually to build a function in a network with direct communication based on the transfer function of the second degree. The method uses information directly from the data sample and minimizes the influence of the author's a priori assumptions on the simulation results; finds regularity in the data and chooses informative input arguments; automatically finds the structure of the model and its parameters.
Any GMDH algorithm solves the problem of discrete optimization to build an optimal model of complexity according to a given minimum of external criteria based on the division of the data sample:

$$
f^{*}=\underset{f \in \Phi}{\arg \min } C R(f),
$$

where $\mathrm{CR}$ is the selection criterion as a measure of the quality of the model $f \in \Phi$. A criterion for selecting a model is called "external" if it is based on additional information that is not contained in the data used to calculate the parameters of the model. A set of comparable models can be formed with the help of iterative or selective generators of model structures of different complexity, differing in different variants of generation and organization of minimum search by a given external criterion based on additional information not contained in the data used to calculate parameters models.

To implement the principle of external complementarity, the least squares parameter estimates are calculated LSM (usually) and the values of the criteria for the different parts of the sample $W=[X, y]$, where $X, y$ matrix and vector with $\mathrm{n}$ measurements $\mathrm{m}$ arguments and one output respectively. 
Input sample $\mathrm{W}$ is divided into two subsets: training $A$ and testing $B$. Regularity criterion calculated for the model $f \in \Phi$, most often used among all GMDH criteria:

$$
\begin{aligned}
A R_{B \mid A}(f) & =\left\|y_{B}-\hat{y}_{B \mid A}(f)\right\|^{2}= \\
& =\left\|y_{B}-X_{B f} \hat{\theta_{A f}}\right\|^{2},
\end{aligned}
$$

which means «model error $f$ on $B$ with the parameters obtained on $A$ " $, X_{A f}, X_{B f}$ are matrix $X$ submatrices, containing columns that correspond to a partial model $f \in \Phi$. One of the main elements of the iterative algorithm of GMDH, namely, a polynomial partial description, can be considered an elementary neuron of the neural network of GMDH.

GMDH NM solves the problem of discrete optimization by consistently approaching the minimum criterion: the complexity of the models on the layer arises due to the pairwise "connection" of the $F$ best models from the previous layer.

The complication process stops after the criterion begins to increase. The originality of the network with such neurons lies in the high speed of local adjustment of the weights of neurons and automatic global optimization of the number of layers. The depth of the GMDH network is determined automatically. GMDH is used in various tasks of data analysis, modeling of nonlinear systems, function approximation, forecasting and modeling, classification, pattern recognition and clustering.

The neural network is designed to solve a specific problem. This may include identifying (approximating), recognizing patterns and situations, or predicting random processes and recurring events based on information contained in a sample of observations of a test or control object.

Modern computer technology has created a new approach in neural networks, which increases the accuracy of classical modeling algorithms. Such multi-row systems can solve complex problems. The idea of active neurons was used to eliminate the shortcomings of MIA GMDH.

\section{Characteristics of GMDH Neural Networks with Active Neurons}

Each neuron is an elementary system that copes with the same task. Neurons for which connections are assigned externally by the person responsible for modeling or other neurons should be called passive neurons. On the contrary, neurons that choose their input variables (through learning or self-organization) that are necessary to minimize a given target function of the neuron can be called active neurons [7].

MIA GMDH neurons (partial descriptions) can be called "passive" if they have the same structure, ie the polynomial neural network is homogeneous. In the 1990s, O.G. Ivakhnenko proposed a new type of GMDH network with active neurons [8], each of which is a bridging or other algorithm of GMDH, due to which the structure of each neuron is optimized. In this case, all neurons can get a different structure, which increases the flexibility of setting up a heterogeneous network for a specific task. Such networks are also called double-row [9].

Connections selected by active neurons uniquely determine the structure of connections for the entire neural network. In general, there is a significant similarity between the self-organization of models and the self-organization of neural networks. Key procedures for self-organizing models, such as selecting a network layer number by exhaustive external search, optimizing sets of input and output variables, and search completion rules, are valid for self-organizing both individual models and neural networks. The goal of combining active neurons into a neural network is to increase the accuracy of the task facing each neuron and the entire neural network. Neurons find themselves in different conditions. They can differ in both output variables and a set of input variables.

It is important to study the features of neural networks with active neurons, to find ideas that help to eliminate some of their shortcomings that could help create more efficient neural networks.

GMDH algorithms, but also many other algorithms for modeling and pattern recognition can also be used as active neurons, the processes of self- 
organization of which are well studied. The function of active neurons can be performed by various recognition systems, in particular Rosenblatt's twolayer perceptrons. Such a neural network achieves the task of pattern recognition. In the case of approximation of relations (identification and extrapolation (prediction) of random processes and repetitive events, the active neurons are GMDH algorithms).

Their accuracy can be increased in two ways:

- each output of the algorithm (active neuron) generates a new variable that can be used as a new feature in the next rows of the neural network;

- many features can be optimized on each row. Signs (including newly generated) can be ranked according to their effectiveness and some of the most effective signs can be used as inputs for subsequent series of neurons. In a conventional singlerow neural network, the set of input variables can be selected only once.

GMDH algorithms are examples of complex active neurons, because they choose the effective inputs and the corresponding coefficients (search for the number of neuronal layers of neurons and sets of input and output variables for each neuron) in the process of self-organization. In the process of learning or self-organization, active neurons choose their input stimuli according to a given criterion and determine the weights of connections. In this way, they organize the structure of the entire neural network. The number of active neurons is determined by the amount of information received for processing as a sample of observations of the test or monitored object. In each layer of the neural network, active neurons differ from each other in sets of input and output variables.

The problem of self-organization of the neural network connection structure is solved in a simple way. Each neuron is an elementary system that solves the same problem. The minimum criterion indicates the variables for which it is advantageous to build a neural network, and how many neural layers should be used. Active neurons are able during the process of self-organization to assess what input is needed to minimize a given target function of the neuron. In a neural network with such neurons, we will have a double multilayer structure: the neurons themselves are multilayer, and they will be combined into a multilayer network. They can provide the generation of new features of a special type (outputs of neurons from the previous layer) and the choice of an effective set of factors on each layer of neurons. The output variables of the previous layers are very efficient secondary inputs for the neurons of the next layer.

Thus, the self-organization of neural networks is in many respects similar to the same procedure for each active neuron. In a neural network with such neurons, we will have a double-row structure: the neurons themselves are multi-row, and they will be combined into a multi-row network. They can provide the generation of new properties of a special type (outputs of neurons of the previous series) and the selection of an effective set of variables on each series of neurons. The output variables of the previous series are very efficient secondary inputs for the neurons of the next series. The sample is expanded only by the inclusion of output variables calculated on each previous row of the neural network. The neuron learning algorithm chooses which of the proposed parameters should be taken into account and estimates the coefficients of connection between them.

Not only GMDH algorithms can be used as active neurons, but also many algorithms for modeling or pattern recognition. Its accuracy can be increased in two ways:

- each output of the algorithm (active neuron) generates a new variable that can be used as a new factor in subsequent layers of the neural network;

- the set of factors can be optimized at each level.

Factors (including new ones) can be ranked according to their effectiveness, and some of the most effective factors can be used as input for subsequent layers of neurons. In a normal multilayer NM, a set of input variables can be selected only once. There are other variants of GMDH-like neural networks with active neurons.

GMDH-like neural network with feedback [10]. A neural network with feedback, when the outputs of neurons of a given layer (series) "intersect" with 
the output variables. The optimal network architecture and its structural parameters are based on self-organization: one of the three architectures for each neuron is automatically selected - sigmoid, radial or polynomial activation function, as well as the number of layers, neurons in layers and input variables.

Evolution of groups of adaptive models [11]. An algorithm called GAME (Group of Adaptive Models Evolution), based on the GMDH architecture, was developed at the Czech Technical University in Prague. The main modifications of this GMDHlike system [11] are also based on the idea of active neurons:

- the transfer function of each node of this heterogeneous network can be linear, polynomial, logistic, RBF and others, as well as in the form of a perceptron, and the choice of type of nodes that form this network is determined by the minimum value of the selection criterion; the number of inputs of each node is equal to the number of the network layer where this node is located;

- there are inter-row connections in the network, and in the process of building the network there are all possible locations of nodes, only their random subsets;

- the original GMDH gives one optimal model, and GAME - a group of the best models, locally optimal for its subset of placements. In this GMDH-like algorithm, the transfer functions, the initial values of the weights and coefficients of the nodes, as well as their inputs are selected randomly, so the topology of the models built on one training sample may differ. Other ways to develop ideas of self-organization.

There are many new trends in the development of methods of self-organization of models based on GMDH: the creation of hybrid architectures in combination with algorithms of computational intelligence [12], the use of parallelization of operations [13], building neural networks with fuzzy activation functions [14] and many others. etc.

The algorithm of the generalized iterative algorithm of GIA GMDH [15-19] is based on the ideas of adding on each row of initial arguments (selection of primary arguments); realization of "active neurons" in the form of combinatorial optimization of the structure of partial models, hybridization of the structures of iterative algorithms of GMDH and combinatorial algorithm COMBI GMDH.

Formally, in general case, a layer of the GIA GMDH may be defined as follows:

1) the input matrix is

$$
X_{r+1}=\left(y_{1}^{r}, \ldots, y_{F}^{r}, x_{1}, \ldots, x_{m}\right)
$$

for a layer $r+1$, where $x_{1}, \ldots x_{m}$, are the initial arguments and $y_{1}^{r}, \ldots, y_{F}^{r}$ are the intermediate ones of the layer $\mathrm{r}$;

2) the operators of the kind

$$
\begin{aligned}
& y_{l}^{r+1}=f\left(y_{i}^{r}, y_{j}^{r}\right), l=1,2, \ldots, C_{F}^{2}, \quad i, j=\overline{1, F}, \\
& y_{l}^{r+1}=f\left(y_{i}^{r}, x_{j}\right), l=1,2, \ldots, F m, i=\overline{1, F}, j=\overline{1, m}
\end{aligned}
$$

may be applied on the layer $r+1$ to construct linear, bilinear and quadratic partial descriptions:

$$
\begin{gathered}
z=f(u, v)=a_{0}+a_{1} u+a_{2} v ; \\
z=f(u, v)=a_{0}+a_{1} u+a_{2} v+a_{3} u v ; \\
z=f(u, v)=a_{0}+a_{1} u+a_{2} v+a_{3} u v+ \\
+a_{4} u^{2}+a_{5} v^{2} .
\end{gathered}
$$

3) for any description, the optimal structure is searched by combinatorial algorithm; e.g., for the linear partial description the expression holds:

$$
f(u, v)=a_{0} d_{1}+a_{1} d_{2} u+a_{2} d_{3} v,
$$

where $d_{k}, k=1,2,3, d_{k}=\{0,1\}$ are elements of the binary structural vector $d=\left(d_{1}, d_{2}, d_{3}\right)$ where values 1 or 0 mean inclusion or not a relevant argument.

Then the best model will be described as $f\left(u, v, d_{\text {opt }}\right)$, where

$$
\begin{gathered}
d_{o p t}=\arg \min _{l=\overline{1, q}} C R_{l}, q=2^{p}-1, \\
f_{o p t}(u, v)=f\left(u, v, d_{o p t}\right) .
\end{gathered}
$$

4) the algorithm stops when the condition $C R^{r}<C R^{r-1}$ is checked, where $C R^{r}, C R^{r-1}$ are criterion values for the best models of $(\mathrm{r}-1)$-th and 


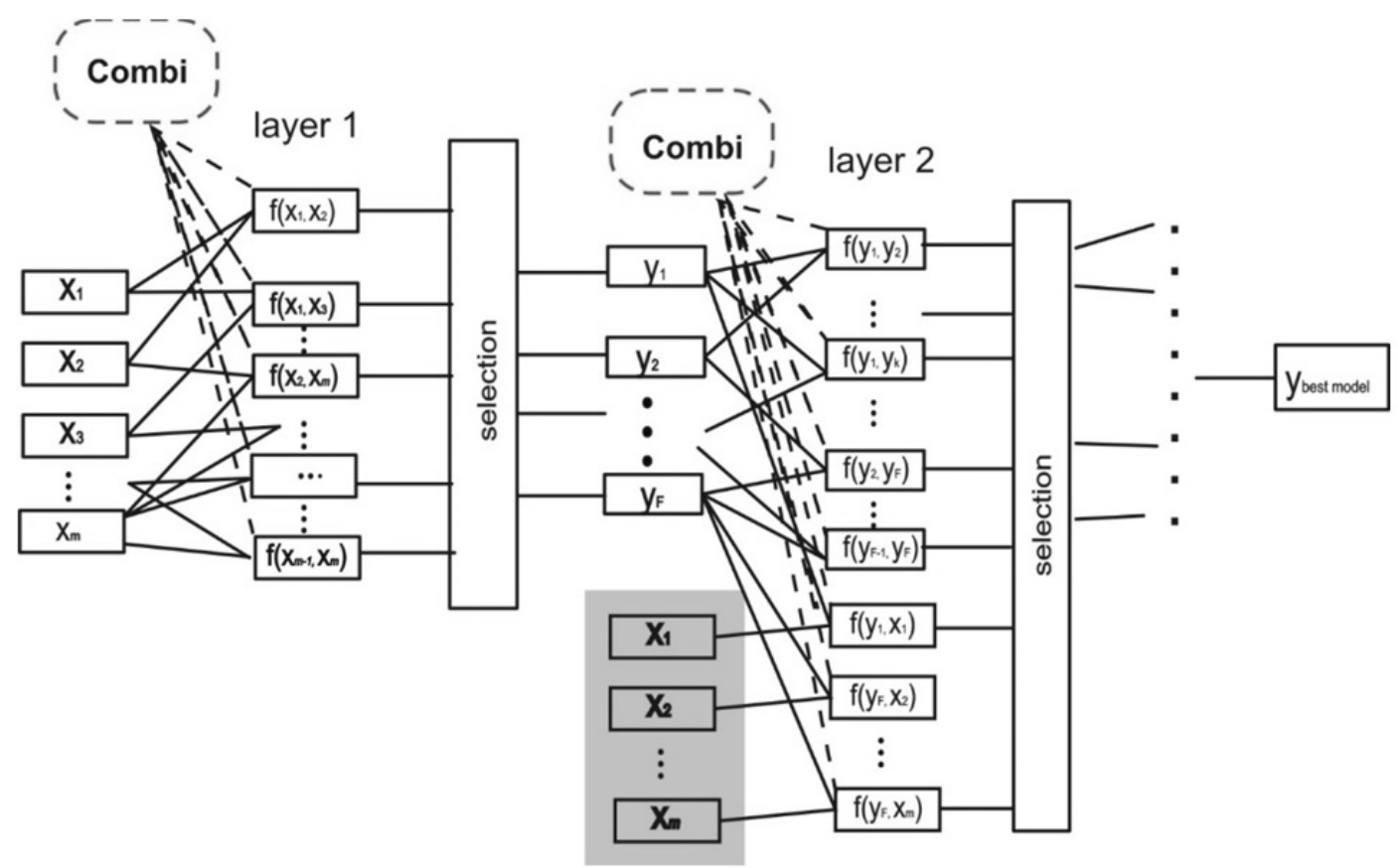

Fig. 2. The generalized architecture of GIA GMDH

r-th layers respectively. If the condition holds, then stop, otherwise jump to the next layer.

The GIA structure is schematically represented in the Fig. 2.

In practice, the generalized iterative algorithm of GMDH has a wide range of applications [20-24], in particular in predicting the consequences of nuclear tests, explosions, activity of chemical compounds, modeling games. sustainable cities and smart infrastructures, business system modeling.

\section{Analysis of the Advantages and Disadvantages of GMDH with Active Neurons}

The hybrid architecture of GIA GMDH [1] provides an effective set of new features: recovery of informative arguments eliminated in the first stages of the algorithm; exclusion of non-informative arguments left in the early stages; prevention of overcomplication of the model due to optimization of the complexity of private models; elimination of "degeneracy" of partial models, ie this algorithmic structure allows not only to generalize the basic structures of previously developed iterative algorithms GMDH and simultaneously obtain new variants, but also to eliminate all four previously noted shortcomings of the classical multi-row algorithm GMDH.

However, GIA GMDH has a significant disadvantage, which is the use of a deterministic combinatorial algorithm for optimization, which requires a significant amount of computing resources and time to find the optimal model. Therefore, there is a need to find alternative approaches to global optimization, in particular using the methods of computational intelligence, which have a stochastic nature.

\section{Approach to Construction of a New Class of GMDH Neural Networks with Active Neurons Using Computer Intelligence Methods}

Based on the analysis of iterative algorithms of GMDH with active neurons, the urgent task of developing the theory and means of self-organization of high-performance neural networks of a new class based on hybridization of MIA GMDH with evolu- 
tionary methods of computational intelligence (CI) for delete GIA GMDH drawbaks is formulated.

Since the most widely used OI methods for learning neural networks are genetic algorithms (GA) [6], the main idea of building a new class of deep networks with active neurons based on MIA GMDH is to create hybrid structures with GA. That is, the neurons of the network will be optimized by a hybrid combinatorial-genetic algorithm, which showed high efficiency of finding the optimal model [6].

\section{CONCLUSIONS}

The article presents the results of the analysis of the main advantages and disadvantages of the existing neural networks of GMDH with active neurons. Their main disadvantage is the use of deterministic methods of optimization of neurons, which leads to the use of a large number of computing and time resources.

To eliminate it, an approach to improving the efficiency of inductive construction of models of complex systems based on statistical data based on the creation of a new class of neural networks GMDH with "active neurons", the structure of which is optimized by a hybrid combinatorial-genetic algorithm.

Namely the idea of creating a new type of GIA GMDH neural network architecture where partical description optimizing by genetic algorithm.

\section{REFERENCES}

1. Stepashko V.S., Bulgakova O.S., Zosimov V.V., 2018. Iterative algorithms for inductive modeling. Kyiv: Naukova dumka, 190 p. (In Ukrainian).

2. Stepashko V.S., Bulgakova O.S., 2013. "Generalized iterative algorithm of the Group Method of Data Handling". Upravlyayushchie Sistemy i Mashiny, pp. 5-17 (In Russian).

3. Stepashko V., Bulgakova O., 2013."Generalized Iterative Algorithm GIA GMDH,” Proceedings of the 4th International Conference on Inductive Modelling ICIM-2013, Kyiv, IRTC ITS NASU, pp. 119-123.

4. Stepashko V.S., 2017. "Developments and prospects of GMDH-based inductive modeling". Conference on Computer Science and Information Technologies, pp. 474-491.

5. Moroz O.H., Stepashko V.S., 2021. Comparative features of MIA GMDH and deep feed-forward neural networks. Cybernetics and computer engineering, 4 (206), pp. 5-20.

6. Moroz O.H., Stepashko V.S., 2021. “ The sorting algorithms of inductive modeling with genetic operators”. Kyiv, Osvita Ukrayiny, 216 p. (In Ukrainian).

7. Ivakhnenko A.G., Ivakhnenko G.A., Mueller J.A., 1995. "Self-organization of neuronets with Active Neurons". Pattern Recognition and Image Analysis, 4 (4), pp. 177-188.

8. Ivakhnenko A.G., Mueller J.-A., 1995. "Self-organization of Nets of Active Neurons". System Analysis Modeling Simulation, 20, pp. 93-106.

9. Ivakhnenko G.A., 2003. "Algorithm for complexing analogs for self-organization of double multi-row neural networks", Upravlyayushchie Sistemy i Mashiny, 2, pp. 100 -106 (In Russian).

10. Kondo T, Ueno J., 2007. "Feedback GMDH-Type Neural Network Self-Selecting Optimum Neural Network Architecture and its Application to 3-Dimensional Medical Image Recognition of the Lungs". Proc. of the II Int. Workshop on Inductive Modelling IWIM-2007, 19-23 Sept. 2007, Prague: Czech Technical University, pp. 63-70.

11. Kordik P., 2006. Fully automated knowledge extraction using group of adaptive model evolution: PhD thesis / Electrical Engineering and Information Technology. Prague: CTU, $150 \mathrm{p}$.

12. Kovarik O, Kordik P., 2008. "Optimizing Models Using Continuous Ant Algorithms". Proc. of the 2nd Int. Conf. on Inductive Modelling ICIM-2008. K.: IRTC ITS NANU, pp. 124-128.

13. Lemke F., 2008. "Parallel Self-Organizing Modeling". Proc. of the 2nd Int. Conf. on Inductive Modelling ICIM-2008. K.: IRTC ITS NANU, pp. 176-184.

14. Bodyanskiy Ye.V., Zaychenko Yu.P, Pavlikovskaya Ye., 2009. “The Neo-Fuzzy Neural Network Structure Optimization Using the GMDH for the Solving Forecasting and Classification Problems". Proc. of the 3rd Int. Workshop on Inductive Modelling IWIM-2009, 14-19 Sept. 2009, Krynica, Poland. Prague: Czech Technical University, pp. 100-107.

15. Stepashko V.S., Bulgakova O.S., Zosimov V.V., 2010. “ Hybrid algorithms for self-organization of models for predicting complex processes”. Inductive modeling of complex systems. Collected research papers, Issue 2, Kyiv: IRTC ITS NASU, pp. 236-246 (In Ukrainian). 
16. Ivakhnenko A.G., Wunsh D., Ivakhnenko G.A., 1999. "Inductive sorting-out GMDH algorithms with polynomial complexity for active neurons of neural networks". Proceedings of the International Joint Conference on Neural Networks, IEEE, Piscataway, New Jersey, pp. 1169-1173.

17. Müller J.-A., Lemke F., 1999. Self-organizing Data Mining. 220 p.

18. Ivakhnenko G.A. Model-Free Analogues as Active Neurons for Neural Network Self-organization. [online] Available at: $<$ http://www.gmdh.net/articles/algor/analogue.pdf $>$ (Accessed 17.09.2021).

19. Stepashko V.S., Bulgakova O.S., Zosimov V.V., 2018. "Construction and research of the generalized iterative GMDH algorithm with active neurons," Advances in Intelligent Systems and Computing, Vol. 689, pp. 492-510.

20. Ivakhnenko A.G., Kovalishyn V.V., Tetko I.V., Luik A.I., Ivakhnenko G.A., Ivakhnenko N.A., 1999. "Application of SelfOrganizing Neural Networks with Active Neurons for Prediction of Bioactivity of Chemical Compounds by the Analogues Search Algorithm". Journal of Automation and Information Sciences, 31 (7-9), pp. 51-58. DOI: 10.1615/JAutomatInfScien. v31.i7-9.90.

21. Ivakhnenko G.A., 1995. "Self-organization of Neuronet with Active Neurons for Effects of Nuclear Tests Explosions Forecasting". System Analysis Modeling Simulation SAMS, 20, pp.107-116.

22. Kovalishyn V.V., Tetko I. V., Luik A.I., Ivakhnenko A.G., 2000. "Application of Self-Organizing Neural Networks with Active Neurons for QSAR Studies". Molecular Modeling and Prediction of Bioactivity, pp. 444-445.

23. Lukosch H.K., 2017. "Simulation gaming. Applications for sustainable cities and smart infrastructures". Proc. of 48th international simulation and gaming association conference, pp. 10-14.

24. Marchev A., Motzev M. and Müller, J-A., 1985. "Applications of Self-Organization Procedures for Business System Models Building”, Automatics, Vol. 1, pp. 37-44.

Received 28.11.2021

\section{ЛІТЕРАТУРА}

1. Степашко В.С., Булгакова О.С. Ітераційні алгоритми індуктивного моделювання. Київ: Наукова думка, 2018. Проект "Наукова книга". С. 180-187.

2. Степашко В., Булгакова А.С. Обобщенный итерационный алгоритм метода группового учета аргументов. Управляющие системы и машины, 2013, № 2. С. 5-20.

3. Stepashko V., Bulgakova O. "Generalized Iterative Algorithm GIA GMDH," Proc. of the 4th Int. Conf. on Inductive Modelling ICIM-2013, Kyiv, Ukraine. Kyiv: IRTC ITS NASU, Sept. 2013. P. 119-123.

4. Stepashko V. Developments and prospects of GMDH-based inductive modeling. Conference on Computer Science and Information Technologies, 2017. P. 474-491.

5. Moroz O.H., Stepashko V.S., 2021. Comparative features of MIA GMDH and deep feed-forward neural networks. Cybernetics and computer engineering, 4 (206). P. 5-20.

6. Мороз О.Г., Степашко В.С. “Перебірні алгоритми індуктивного моделювання з генетичними операторами” Освіта України. Київ. 2021. 216 с.

7. Ivakhnenko A.G., Ivakhnenko G.A., J.-A. Mueller. Self-organization of neuronets with Active Neurons. Pattern Recognition and Image Analysis. 1995. 4 (4). P. 177-188.

8. Ivakhnenko A.G., Mueller J.-A. Self-organization of Nets of Active Neurons. System Analysis Modeling Simulation SAMS. 1995. 20. P. 93-106.

9. Ивахненко Г.А. Алгоритм комплексирования аналогов для самоорганизации дважды многорядных нейронных сетей. Управляющие системы и машины. 2003. № 2. С. 100 -106.

10. Kondo T, Ueno J. Feedback GMDH-Type Neural Network Self-Selecting Optimum Neural Network Architecture and its Application to 3-Dimensional Medical Image Recognition of the Lungs / Proc. of the II Int. Workshop on Inductive Modelling IWIM-2007, 19-23 Sept. 2007, Prague. Prague: Czech Technical University, 2007. P. 63-70.

11. Kordik P. Fully automated knowledge extraction using group of adaptive model evolution: $\mathrm{PhD}$ thesis. Electrical Engineering and Information Technology. Prague: CTU, 2006. 150 p.

12. Kovarik O, Kordik P. Optimizing Models Using Continuous Ant Algorithms. Proc. of the 2nd Int. Conf. on Inductive Modelling ICIM-2008. K.: IRTC ITS NANU, 2008. P. 124-128.

13. Lemke F. Parallel Self-Organizing Modeling. Proc. of the 2nd Int. Conf. on Inductive Modelling ICIM-2008. K.: IRTC ITS NANU, 2008. P. 176-184. 
14. Bodyanskiy Ye.V., Zaychenko Yu.P, Pavlikovskaya Ye. The Neo-Fuzzy Neural Network Structure Optimization Using the GMDH for the Solving Forecasting and Classification Problems. Proc. of the 3rd Int. Workshop on Inductive Modelling IWIM-2009, 14-19 Sept. 2009, Krynica, Poland. Prague: Czech Technical University, 2009. P. 100-107.

15. Степашко В.С., Булгакова О.С., Зосімов В.В. Гібридні алгоритми самоорганізації моделей для прогнозування складних процесів. Індуктивне моделювання складних систем: Зб. наук. праць. К.: МННЦІТ та С НАНУ, 2010. 2. C. $236-246$.

16. Ivakhnenko, A.G., Wunsh, D. and Ivakhnenko, G.A.: Inductive sorting-out GMDH algorithms with polynomial complexity for active neurons of neural networks. In: Proceedings of the International Joint Conference on Neural Networks, IEEE, Piscataway, New Jersey, 1999. P. 1169-1173.

17. Müller J.-A., Lemke F. Self-organising Data Mining. 1999. p. 220.

18. Ivakhnenko G.A. Model-Free Analogues as Active Neurons for Neural Network Self-organization. [online] Available at: $<\mathrm{http}: / /$ www.gmdh.net/articles/algor/analogue.pdf $>$.

19. Stepashko V., Bulgakova O., Zosimov V. Construction and research of the generalized iterative GMDH algorithm with active neurons. Conference on Computer Science and Information Technologies. 2017. P. 492-510.

20. Stepashko V.S., Bulgakova O.S., Zosimov V.V. "Construction and research of the generalized iterative GMDH algorithm with active neurons," Advances in Intelligent Systems and Computing, Vol. 689, 2018. P. 492-510.

21. Ивахненко А.Г., Ковалишин В.В., Тетко И.В., Луйк А.И., Ивахненко Г.А., Ивахненко Н.А. Самоорганизация нейросетей с активными нейронами для прогнозирования активности химических соединений на основе алгоритма поиска аналогов. Пробл. упр. и информатики. 1999. 1. С. 69-77.

22. Ivakhnenko G.A. Self-organization of Neuronet with Active Neurons for Effects of Nuclear Tests Explosions Forecasting. System Analysis Modeling Simulation SAMS. 1995. 20, 4. P.107-116.

23. Lukosch H.K. Simulation gaming. Applications for sustainable cities and smart infrastructures. 48th international simulation and gaming association conference, 2017. P. 10-14.

24. Marchev A., Motzev M. and Müller, J-A. Applications of Self-Organization Procedures for Business System Models Building", Automatics, 1985. Vol. 1, P. 37-44.

Надійшла 28.11.2021 
Мороз О. Г., старший. наук. співробітник, Міжнародний науково-навчальний центр інформаційних технологій та систем НАН та МОН України, просп. Глушкова, 40, Київ 03187, Україна, olhahryhmoroz@gmail.com

\section{ЗАДАЧА КОНСТРУЮВАННЯ НЕЙРОМЕРЕЖ МГУА З АКТИВНИМИ НЕЙРОНАМИ}

Вступ. Нейронні мережі на основі багаторядного ітераційного алгоритму групового урахування аргументів (БІА МГУА) є ефективними інструментами для вирішення актуальних проблем прогнозування, аналізу даних, розпізнавання образів, кластеризації, класифікації тощо. Існує багато типів нейронних мереж МГУА, розробка яких спрямована на підвищення ефективності індуктивної побудови моделей складних систем за статистичними даними. Основними недоліками класичної нейронної мережі МГУА є: можливість втрати інформативних аргументів, якщо вони були втрачені на початку пошуку; можливість фіксації неінформативних аргументів, якщо вони були включені на початку пошуку; експоненційне зростання степеня полінома в квадратичному описі; зі збільшенням кількості ітерацій вихідні вектори кращих моделей стають все більш корельованими, що погіршує умовність систем рівнянь для оцінки параметрів.

Останньою модифікацією багаторядкових алгоритмів МГУА для усунення їхніх недоліків є узагальнений ітераційний алгоритм МГУА, який базується на поєднанні ідей щодо збереження початкової бази моделювання та застосування оптимізації складності до частинних моделей з використанням так званих «активних нейронів» 3 різною структурою, яка оптимізується комбінаторним алгоритмом МГУА. Його окремими випадками є алгоритми багаторядкового та релаксаційного типів, а також деякі типи ітераційно-комбінаторних (гібридних) алгоритмів.

У цій роботі досліджуються переваги та недоліки існуючих архітектур нейронних мереж МГУА прямого поширення з метою подальшої побудови більш ефективного нового класу нейронних мереж МГУА з активними нейронами, оптимізованими за допомогою гібридного комбінаторно-генетичного алгоритму.

Метою статті $€$ дослідження переваг та недоліків наявних архітектур нейромереж МГУА для підвищення ефективності індуктивної побудови моделей складних систем за статистичними даними на основі створення нового класу нейромереж МГУА з активними нейронами.

Методи. У роботі представлено опис основних нейромереж МГУА з активними нейронами.

Результати. Подано характеристику наявних нейромереж МГУА з активними нейронами, проаналізовано ї основні переваги та недоліки. Серед основних недоліків нейромережі МГУА виявлено такі: експоненційний ріст степеня полінома в квадратичному частинному описі, можливість втрати інформативних і закріплення неінформативних аргументів в моделі.

Запропоновано підхід до підвищення ефективності індуктивної побудови моделей складних систем за статистичними даними на основі створення нового класу нейромереж МГУА з активними нейронами, що мають різну структуру, яка оптимізується генетичним алгоритмом.

Висновки. У статті наведено результати аналізу основних переваг та недоліків існуючих нейронних мереж МГУА з активними нейронами. Основним недоліком є використання детермінованих методів оптимізації нейронів, що призводить до використання великої кількості обчислювальних і часових ресурсів. Для його усунення розроблено підхід до підвищення ефективності індуктивної побудови моделей складних систем на основі статистичних даних на основі створення нового класу нейронних мереж МГУА з «активними нейронами», структура яких оптимізується генетичним алгоритм.

Ключові слова: індуктивне моделювання, нейромережа МГУА, активні нейрони, обчислювальний інтелект, генетичні алгоритми. 